\title{
2007 Florida Plant Disease Management Guide: Apple (Malus sylvestris) 1
}

Tim Momol, Laura Ritchie, and Hank Dankers ${ }^{2}$

\section{APPLE SCAB}

\section{Introduction:}

Apple scab is an economically important disease resulting in direct loss from fruit or pedicel infections. Indirectly, repeated defoliation reduces tree growth and yield. In the southeastern United States, however, apple scab severity is inconsistent due to the necessity of cool, wet weather for infection.

\section{Symptoms:}

Young leaf lesions are olive green with indistinct margins. As the infected leaf ages, several lesions may coalesce and tissues adjacent to lesions thicken, causing the leaf to become curled, dwarfed, or distorted (Fig. 1).

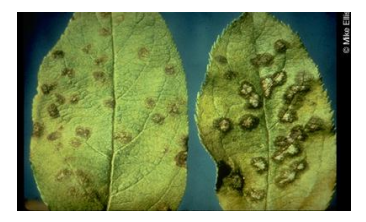

Figure 1. Apple scab on apple leaf caused by Venturia inaequalis. Credits: Ohio State University Extension
Fruit lesions are similar to those of leaves; however, as infected fruit enlarge the lesions become brown and corky. Early season infection may result in uneven fruit development, further causing cracks in the skin and flesh (Fig. 2). Late season infection may result in pin-point scab where circular lesions are rough and black.

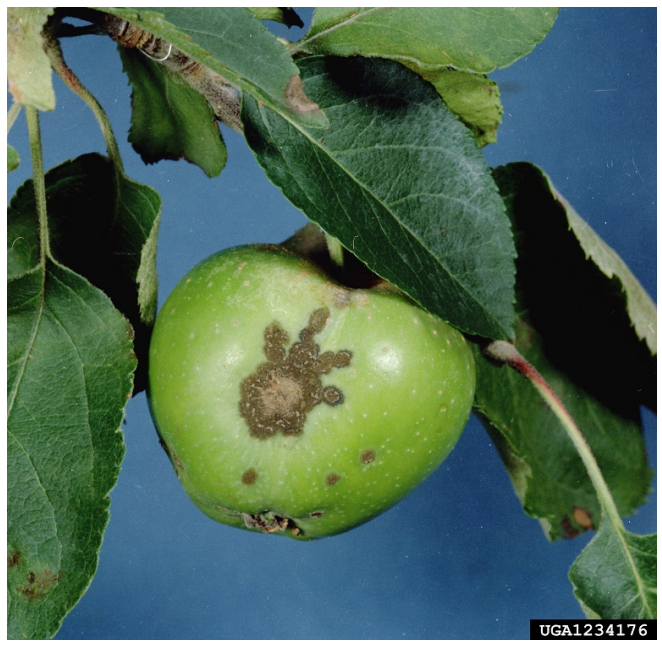

Figure 2. Apple scab on apple fruit caused by Venturia inaequalis. Credits: Clemson University - USDA Cooperative Extension Slide Series (IPM Images, The Bugwood Network)

1. This document is Fact Sheet PP-240, one of a series of the Plant Pathology Department, Florida Cooperative Extension Services, Institute of Food and Agricultural Sciences, University of Florida. Published October 2007. Please visit the EDIS Website at http://edis.ifas.ufl.edu/

2. Tim Momol, associate professor, North Florida Research and Education Center (NFREC), Quincy, FL 32351; Laura Ritchie, Biologist, NFREC; and Hank Dankers, senior biologist, NFREC, Cooperative Extension Service, Institute of Food and Agricultural Sciences, University of Florida, Gainesville, FL 32611.

The Institute of Food and Agricultural Sciences (IFAS) is an Equal Opportunity Institution authorized to provide research, educational information and other services only to individuals and institutions that function with non-discrimination with respect to race, creed, color, religion, age, disability, sex, sexual orientation, marital status, national origin, political opinions or affiliations. U.S. Department of Agriculture, Cooperative Extension Service, University of Florida, IFAS, Florida A. \& M. University Cooperative Extension Program, and Boards of County Commissioners Cooperating. Larry Arrington, Dean 


\section{Causal Organism:}

Venturia inaequalis is the causal organism of apple scab. Pseudothecia, produced in overwintered leaves or fruit, are separate, dark brown to black, spherical, with a short beak and distinct ostioles with single-celled bristles at the apex. Asci are fasciculate, cylindrical, short-stipitate, eight-spored and have thin, bitunicate walls. Ascospores are yellowish green to tan and unequally two-celled. Conidia are olive, have one or two cells, are ovate to lanceolate and are produced sequentially by a series of abscission ridges on the conidiophore.

\section{Disease Cycle and Epidemiology}

V. Inaequalis overwinters in infected fruit and leaves on the ground. As infected fruit and leaves become wet asci discharge ascospores which are disseminated by the wind, initiating primary infections on new growth. Free moisture is required for the germination of an ascospore on the new leaf or fruit. After initiation, germination will continue as long as the relative humidity is $95 \%$ or greater. After fungal penetration of the cuticle, conidiophores and conidia are produced in a visible lesion. Conidia are then disseminated by rain and wind to new leaves and fruit, initiating a secondary infection cycle.

\section{Management:}

Removal of fallen leaves and fruit in the fall can reduce disease inoculum. Attention to weather forecasts, particularly those of extended wet periods, can assist in chemical control. See Table 1.

\section{BITTER ROT}

\section{Introduction:}

Bitter rot is an important summer disease of apples grown in the southern United States. During periods of warm, moist weather bitter rot can destroy an entire crop within a few weeks.

\section{Symptoms:}

Fruit infections begin as small, circular, tan to light brown spots that expand rapidly under warm, moist conditions. As the lesion sinks into the fruit surface it is covered with rings of spore masses which appear creamy and salmon to pink in color (Fig. 3). The fruit may become soft and watery, developing a sour rot odor, then drying to a darker, leathery appearance.

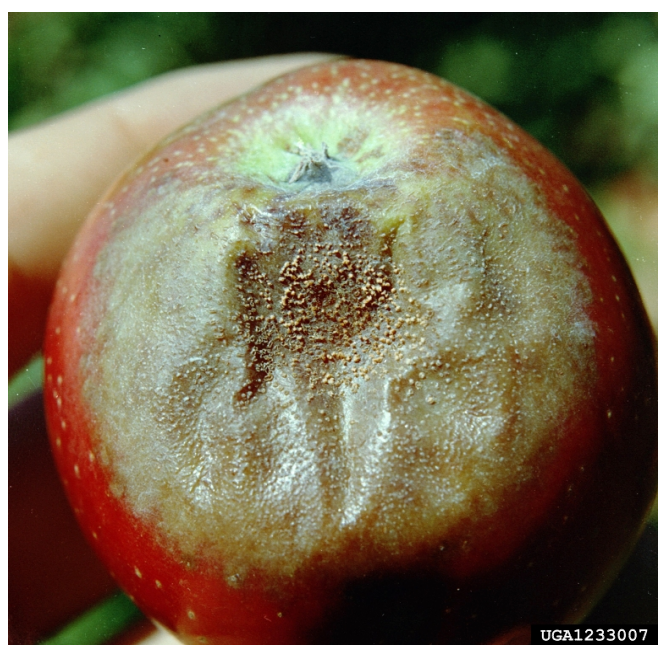

Figure 3. Bitter rot lesion on apple fruit caused by Colletotrichum gloeosporiodes. Note creamy spore massses on lesion surface. Credits: Clemson University USDA Cooperative Extension Slide Series (IPM Images, The Bugwood Network)

The pathogen can form cankers on twigs and cause leaf spots as well. Although not as common, lesions on leaves start as small, red flecks which enlarge to irregular brown spots. Severely infected leaves often abscise.

\section{Causal Organism:}

Colletotrichum gloeosporioides (teleomorph Glomerella cingulata) is the causal organism of bitter rot. Acervuli are produced beneath the cuticle, which is ruptured by the growth of conidiophores and conidia. Conidia are uninucleate, vary in size and shape, and are produced in pink to salmon, sticky masses. Perithecia can be solitary or aggregated, dark brown to black and vary in size and shape. Asci vary in size and are clavate to cylindrical; ascospores vary in size, are slightly curved and unicellular.

\section{Disease Cycle and Epidemiology:}

Fruit infection, through direct penetration or through wounds, is most common from midseason to late in the growing season. Infected fruit, mummified apples (from chemical thinning), and newly colonized dead tissues can serve as additional inoculum during the growing season. Lesion 
expansion is most rapid in warm weather (around $85^{\circ} \mathrm{F}$ ). Prolonged warm, wet weather can lead to epidemics and extensive losses. A warm, wet early season can be the most severe as the primary infection provides abundant secondary inoculum.

Perithecia and acervuli of $C$. gloeosporioides survive from one season to the next in mummified apples, dead wood and cankers. Mummified apples and stems left on the tree provide over wintering sites, mummified fruit on the ground can serve as a source of inoculum.

\section{Management:}

Management of bitter rot is based on sanitation and a fungicide spray program. Removal of mummified fruit, cankers, dead wood and blighted branches from the previous season as well as throughout the current growing season will remove potential inoculum sources. Removal of fruit infected with $C$. gloeosporioides during the growing season will also help slow the spread of disease.

No commercial cultivar is sufficiently resistant to bitter rot to negate the need for sprays. Fungicides should be applied on a 10-14 day schedule from first cover until harvest. See Table 1.

\section{BLACK ROT}

\section{Introduction:}

Black rot of apples occurs throughout the eastern United States but is most severe in the southeast. Losses from the disease come not only from fruit rot, but from the weakening of trees due to limb cankers and leaf spot-induced defoliation

\section{Symptoms:}

Leaf lesions begin as small purple flecks which enlarge and develop a tan to brown center, giving a frog eye appearance (Fig. 4). Heavily infected leaves may become chlorotic and abscise. Fruit symptoms from direct infection begin as minute red flecks which develop into raised purple spots bordered by a red ring. Upon maturation of fruit the lesions will darken and enlarge (Fig. 5), often with alternating black and brown concentric rings.

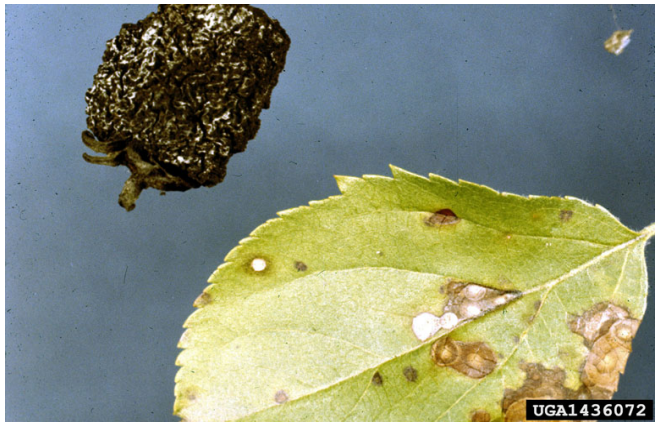

Figure 4. 'Frog eye' appearance of Black rot lesions on appple leaf. Credits: Clemson University - USDA Cooperative Extension Slide Series (IPM Images, The Bugwood Network)

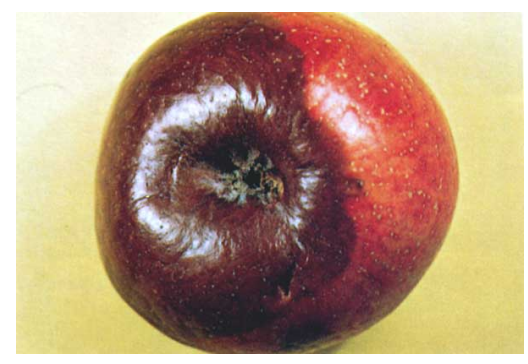

Figure 5. Black rot fruit decay. Credits: Clemson University - USDA Cooperative Extension Slide Series (IPM Images, The Bugwood Network)

Limb cankers begin as slightly sunken reddish brown areas in the bark and can lead to a superficial hardening of the bark or the canker may cause the wood to crack open and die. Fruit may develop rotting around the core, yet remain on the tree, ripening 3-6 weeks before harvest and often dropping before the rot appears on the surface.

\section{Causal Organism:}

Botryosphaeria obtusa (anamorph Sphaeropsis malorum) is the causal organism of black rot. Pycnidia, commonly found on infected wood and fruit, are globose, solitary or botryose, and stromatic with papillate ostioles. At maturity, conidia are nonsepate, ovoid, melanized, with a rough or faintly echinulate wall. Asci are bitunicate and eight-spored; ascospores are fusiform and occasionally one-septate. Pseudothecia are rare in the southeastern United States. 


\section{Disease Cycle and Epidemiology:}

B. obtusa can survive between seasons in tree cankers and mummified apples providing an early season source of inoculum. Mummified apples, wounded bark, and fire-blighted twigs are rapidly colonized by $B$. obtusa and provide inoculum during the growing season. Conidia and ascospores are released from fruiting structures during rainfall throughout the year in the southern United States. Infection can occur through stomata of leaves or fruit (early season), and through wounds and cracks in the fruit cuticles (later season).

\section{Management:}

Throughout the season fire-blighted twigs should be removed to lessen the colonization cites for $B$. obtusa. Mummified apples and dead wood should be pruned and removed from the orchard or burned. Black rot is best controlled through chemical applications. See Table 1.

\section{BOTRYOSPHAERIA ROT/WHITE ROT}

\section{BOTRYOSPHAERIA ROT/WHITE ROT}

\section{Introduction:}

Botryosphaeria rot, also referred to as Bot rot or white rot, has symptoms similar to black rot. This disease can have a severe impact in the southeast United States. Extensive fruit losses (50\%) have been reported and cankers can cause the loss of scaffold limbs and possible tree death.

\section{Symptoms:}

Fruit lesions begin as small, slightly sunken brown to tan spots, often surrounded by a red halo (halo may appear purple to black on red cultivars). The rotted area extends in a cylindrical manner to the core as the lesions expand in diameter (Fig. 6), forming a v-shaped lesion in cross section. This criterion can be used as a distinction between black rot and Botryosphaeria rot.

Limb and twig infections begin as small, sunken, oozing lesions, often red in color. The lesions

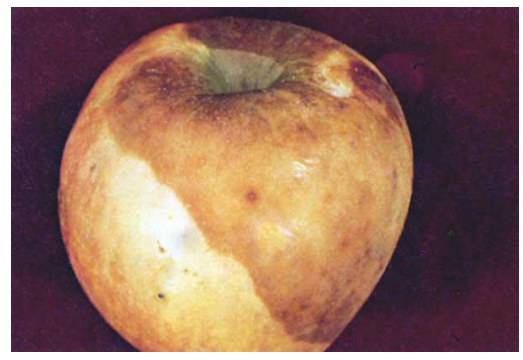

Figure 6. Botrosphaeria rot/White rot of friut. Credits: The Bugwood Network, Insect and Disease Indentification Guide for IPM in the Southeast, The University of Georgia, Cooperative Extension Service Bulletin 849, September 1981

enlarge, exhibiting rings of black Pycnidia and loss of bark (Fig. 7).

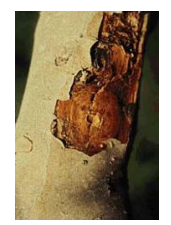

Figure 7. Botryospaeria canker on apple limb. Credits: Michael A. Ellis, The Ohio State University

\section{Causal Organism:}

Botryosphaeria dothidea (anamorph Fusicoccum aesculi) is the causal organism of Botryosphaeria rot. Pycnidia, found on infected wood and fruit, are

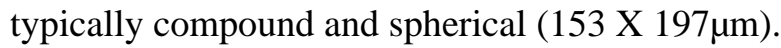
Conidia are nonseptate and hyaline. Ascostroma are solitary and scattered, botryose, ostiolate, and spherical. Asci are cylindrical, eight-spored, and bitunicate; ascospores are hyaline, one-celled, and ovoid.

\section{Disease Cycle and Epidemiology:}

Although ascospores and conidia are produced throughout the growing season in the southeastern United States, inoculum production is dependent on temperature (optimum $82-90^{\circ} \mathrm{F}$ ) and number of spores released is dependent upon the amount and duration of rain. Infection by spores is most common through wounds in fruit, twigs and limbs, although twig and limb infection is often associated with the periods of hot and dry weather.

Mycelium, pycnidia, and pseudothecia of $B$. dothidea survive between seasons in cankers, colonized dead bark, and mummified fruit. $B$. dothidea can colonize in current-season mummified 
fruit and fire blight strikes to provide a secondary source of inoculum.

\section{Management:}

Dead limbs, cankers and mummified fruit should be pruned and removed from the orchard.

Current-season fire blight strikes should be removed to lessen colonization of B. dothidea. Limb and branch infections can also be reduced by irrigation during hot, dry periods. Severity of Botryosphaeria rot in the area and whether early-season latent infections are common are the deciding factors for chemical control timing. See Table 1.

\section{CERCOSPORA LEAF SPOT}

\section{Introduction:}

Cercospora leaf spot is a minor foliar disease of apple which may cause early defoliation.

\section{Symptoms:}

Lesions on infected leaves are round to oblong, often with a zonate appearance.

\section{Causal Organism:}

Pseudocercopsora mali is the causal organism of cercospora leaf spot. Produced in clusters, conidiophores are dark in color, sparingly branched and septate. Conidia are typically hyaline, long and slender and septate.

\section{Management:}

Fallen infected leaves should be removed from the area and destroyed. See Table 1 for chemical control.

\section{CROWN GALL}

\section{Introduction:}

Crown gall affects woody and herbaceous plants from over 90 families, including apples grown for fruit production and ornamental use. Crown gall is variable in severity but gradually lowers tree vigor and may lead to tree death.

\section{Symptoms:}

Galls, varying in size, form on the crown, roots, trunk or limbs. The texture of a gall can range from soft and spongy to hard, depending on the amount of vascular tissue it contains (Fig. 8). Careful diagnosis of smaller galls is important, as they may be confused with excessive callus growth around wound sites, or with nematode or insect induced galls.

\section{Causal Organism:}

Agrobacterium tumefacien bacteria is the causal organism of crown gall. It lacks endospores, is rod-shaped, gram-negative, aerobic and motile by one to six flagella. A large extrachromosomal piece of DNA, commonly referred to as a tumor-inducing (Ti) plasmid), is carried by A. tumefaciens.

\section{Disease Cycle and Epidemiology:}

Wounds are essential to the infection process and initiation of the disease cycle. A. tumefaciens enters through a wound, attaches to a susceptible plant cell and inserts transfer DNA (T-DNA) from the Ti plasmid into the plant cell chromosome. Expression of the T-DNA results in overproduction of plant hormones, stimulating plant cells to divide, enlarge and form a gall. The pathogen may move from galls to surrounding roots and soil, then disseminate to new plants or planting sites by rain, irrigation water, wind, insects, tools, and plant parts used for propagation.

\section{Management:}

Good cultural and sanitation practices are key deterrents to crown gall. These include choosing a rootstock with low susceptibility, budding rather than grafting, developing management practices that minimize wounding, removing young infected trees as well as older galled trees, and dipping shears in rubbing alcohol for 10-15 seconds between cuts. Planting sites where galled plants were grown should be left fallow for several years.

Effectiveness of chemical control through soil fumigation and rootstock dipping varies. 


\section{ENTOMOSPORIUM LEAF SPOT}

\section{Introduction:}

Entomosporium leaf spot usually begins in early summer. In other references, this disease may be referred to as Fabraea leaf spot.

\section{Symptoms:}

Initially, leaf lesions appear as small, purplish, circular spots. Lesions will become sunken, with a raised dark purple to black border, and a gray to white center. Within the center is a small, dark, mound-like fruiting body (acervulus).

\section{Causal Organism:}

Entomosporium mespili is the causal organism of entomosporium leaf spot. Conidia have a distinct insect-like appearance, composed of four cells (lateral cells smaller than central cells) and bristle-like appendages on all but the basal cells. Asci, containing eight hyaline, clavate two-celled ascospores, extend above the leaf cuticle surface when the ascospores are mature.

\section{Disease Cycle and Epidemiology:}

E. mespili overwinters in infected leaves and twig cankers as ascospores and conidia. Rain and overhead irrigation spread the spores to susceptible tissue. Severity increases when wet springs follow mild winters.

\section{Management:}

Infected leaves and twigs should be removed from the area and destroyed by burial or composting and burning. Adequate spacing between rows and avoidance of overhead irrigation will allow good airflow and rapid drying of the foliage. Chemical control may be difficult if primary leaf and twig infections are abundant. See Table 1.

\section{FIRE BLIGHT}

\section{Introduction:}

Fire blight is one of the most devastating bacterial diseases affecting apple, pear and other rosaceous plants. This disease varies in severity from year to year, dependent upon temperature and precipitation. Additionally, fire blighted wood can provide a suitable site for other diseases such as black rot and white rot.

\section{Symptoms:}

Plant parts affected by fire blight appear scorched by fire. Infected blossoms may exhibit ooze, and then change color from red to brown to black as the disease progresses. Infected leaves will turn brown to black and desiccate, yet remain attached to the branches. Vegetative shoots often wilt and take on the shape of a shepherds crook (Fig. 8), the pith of infected stems exhibiting a dark brown discoloration. The outer bark of infected branches and limbs are often sunken and darker than normal, whereas the inner tissues will be water-soaked with reddish streaks while the pathogen is active, later turning brown.

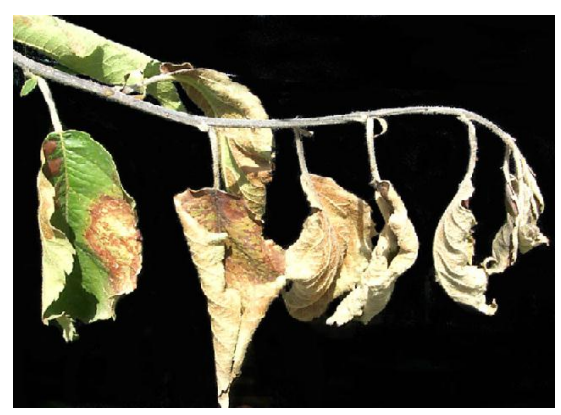

Figure 8. Fire blight on apple branch. Credits: Tim J. Smith, Washington State University

Fruit infected during the early-season remain attached to the cluster base, yet remain small and appear shriveled and dark, whereas fruit infected as the disease progresses from the branches appear less shriveled and dark. Fruit infected following injury often develop red, brown or black lesions, and may exude an ooze which first appears clear or milky, later turning red to brown. 


\section{Causal Organism:}

Erwinia amylovora is the causal organism of fire blight. The rod-shaped bacterium is gram-negative and facultatively anaerobic. Isolation and tentative identification can be made using several selective or differential media; rigorous identification requires additional biochemical and molecular testing.

\section{Disease Cycle and Epidemiology:}

E. amylovora overwinters in small twig cankers and dead wood to provide an initial source of inoculum early in the next season. Transferred by rain or insects, the bacterium penetrates host tissue at wounds or natural openings. Inoculum produced as ooze from fresh infections can serve as a secondary source of disease for later-season vegetative shoots, blossoms and fruits. Lesion extension slows in late summer to autumn in response to less favorable conditions.

Severity of fire blight varies from season to season, dependent upon the interaction of a susceptible plant, a virulent pathogen, and favorable weather conditions. Plant susceptibility varies with plant age, phonological stage and horticultural practices employed; strains of E. amylovora vary in virulence toward plant genotypes. Weather conditions, particularly temperature and moisture, affect vector activity (primarily bees) and pathogen growth.

\section{Management:}

Overwintering cankers should be removed during the dormant season. Active lesions should be pruned out at least 6-8 inches below obvious discoloration. Pruning tools must be disinfected between cuts to reduce spread of the bacterium.

Susceptible cultivars and rootstocks should be avoided, as should the use of nitrogen fertilizers early in the season and late-summer cultivation. There are forecasting models available to time chemical applications. Properly timed chemical applications can be highly effective against the blossom phase of fire blight. See Table1.

\section{FLY SPECK}

\section{Introduction:}

Flyspeck is a common disease of apple whereby fruit quality is lowered by fungal growth on the fruit surface. Due to the warm, moist weather, fungicide use is essential in the southeastern United States.

\section{Symptoms:}

Flyspeck colonies on fruit surfaces are well-defined groupings of shiny, black, superficial pseudothecia (Fig. 9). Colony size varies from $1-3 \mathrm{~cm}$ and round to irregular. Conidiophores and conidia are produced within the colonies of pseudothecia during warm, moist weather.

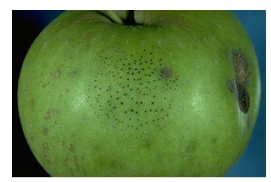

Figure 9. Credits: Michael A. Ellis, The Ohio State University

\section{Causal Organism:}

\section{Schizothyrium pomi (formerly Microthyriella} rubi; anamorph Zygophiala jamaicensis) is the causal organism of flyspeck. Pseudothecia vary in size and have irregular margins. Embedded in a centrum tissue asci are spherical to oval and bitunicate, each ascus containing eight hyaline, two-celled ascospores. The upper cells of ascospores are shorter and wider than the basal cells. Conidiophores consist of a subhyaline basal cell; a smooth, thick-walled brown sector; an angular, subhyaline terminal cell; and two hyaline conidiogenous cells. Two-celled conidia are thin-walled and elliptical to obovate.

\section{Disease Cycle and Epidemiology:}

S. pomi overwinters as pseudothecia on infected apple twigs and woody reservoir hosts. Airborne ascospores are released by the pseudothecia just prior to bloom and germinate from $60.8^{\circ} \mathrm{F}$ to $82.4^{\circ} \mathrm{F}$. Under optimum conditions $\left(63.1^{\circ} \mathrm{F}\right.$, relative humidity above $96 \%$ ) conidia may be produced in 10-12 days. Airborne conidia are released after 
sunrise as the relative humidity declines and the twigs dry, providing the secondary inoculum.

\section{Management:}

During normal to dry weather, well-pruned trees will usually have less disease; during wet seasons well-pruned and poorly pruned trees may be equally diseased. Proper thinning of fruit can lessen the microclimate for disease development that tightly clustered fruit provides and allows for thorough coverage of fungicide sprays. Primary control of flyspeck is through fungicide sprays. See Table 1.

\section{MUSHROOM ROOT ROT}

\section{Introduction:}

Mushroom root rot is also known as Armillaria root rot, oak root fungus disease, and shoestring root rot.

\section{Symptoms:}

Foliage may turn yellow, then brown and dry rapidly. Dark brown to black rhizomorphs, or "shoestrings" appear at the soil line around the trunk of the tree. A creamy white layer of fungus is often present between the bark and the wood; a white to light yellow mycelial growth within the bark of surface roots. Honey-colored mushrooms may form in groups around the drip line of the tree or next to the trunk during moist periods.

\section{Causal Organism:}

Armillaria tabescens is the causal organism of mushroom root rot. Lacking an annulus on the stipe of the mushroom (basidiocarp), it is easily distinguished from other Armillaria species. Blackish, hardened, mycelial extrusions are produced on the bark of infected roots.

\section{Disease Cycle and Epidemiology:}

In recently-cleared woodland (particularly that which had oak cover), rhizomorphs and mycelial strands of the fungus can remain on infected roots in the soil for many years, serving as an initial source of inoculum for new orchard trees. Rhizomorphs also spread between trees, attaching to the roots of a new host and entering through pressure and enzymatic activity.

\section{Management:}

Location of orchard plantings is important. New trees should not be planted in recently cleared woodland (particularly that which had oak cover), near existing stumps or buried debris, nor where trees have recently died from mushroom root rot, unless the root system has been removed in its entirety and several years of fallow have passed. Fumigation of soil can assist in control of mushroom root rot.

\section{PINK LIMB BLIGHT}

\section{Symptoms:}

Pink limb blight produces a pale pink mycelium which often encircles limbs, twigs and trunks of trees. The foliage distal from the affected area wilts and dies, eventually killing the limb or twig.

\section{Causal Organism:}

\section{Erythricium salmonicolor (anamorph Necator} decretus).

\section{Management:}

Infected tissue should be removed immediately; pruning limbs a minimum of 4-6 inches below the external appearance of mycelium on twigs. Prunings should be collected and destroyed.

\section{POWDERY MILDEW}

\section{Introduction:}

A persistent disease, the severity of powdery mildew and resulting economic loss varies with environmental conditions, cultivar susceptibility, and management practices. Powdery mildew can be especially damaging in nursery production.

\section{Symptoms:}

Infections on leaves first appear on the lower surface as grayish-white patches of mycelium and spores, with chlorotic spots on the upper surface. 
Infections may spread to the upper surfaces, covering the entire leaf and eventually turning brown. Leaves infected along the margin may curl, while severely infected leaves may fold longitudinally, become brittle and abscise.

Infected flower buds will open 5-8 days later than healthy buds and exhibit reduced fruit set; flower petals will be distorted and pale yellow or light green. Apples affected during bloom will be stunted in growth and covered with a network pattern of cork cells (russet) that may be so closely woven as to appear as a solid patch (Fig. 10).

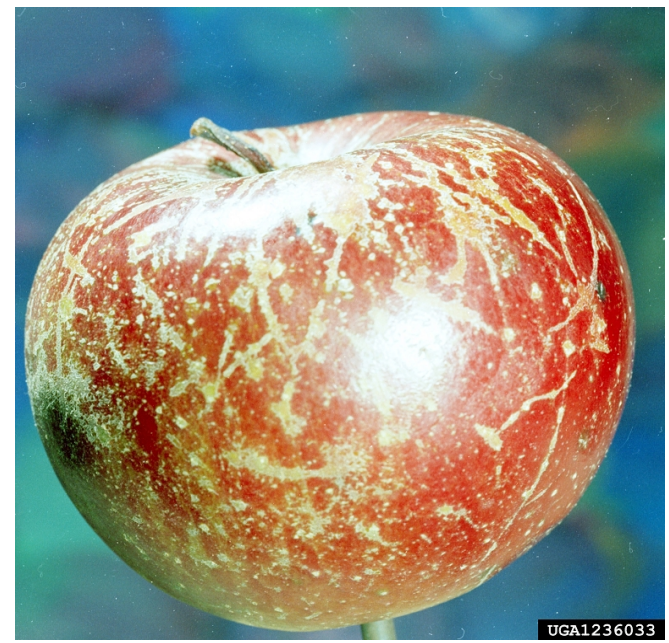

Figure 10. permission needed, sent E-Mail Credits: Clemson University - USDA Cooperative Extension Slide Series (IPM Images, The Bugwood Network)

\section{Causal Organism:}

\section{Podosphaera leucotricha (anamorph Oidium} farinosum) is the causal organism of powdery mildew on apple. Produced in long chains on thin, amphigenous mycelium, conidia are ellipsoidal, truncate, hyaline, and contain fibrosin bodies. Perithecia are densely gregarious and subglobulose, with apical and basal appendages. Apical appendages are three to seven times longer than the diameter of the perithecium, brown basally and widely spreading or erect-fasticulate. Rudimentary basal appendages are pale brown, short-tortuous, and simple or irregularly branched. Asci are oblong to subglobulose and contain 8 ovate to elliptical ascospores.

\section{Disease Cycle and Epidemiology:}

$P$. leucotricha overwinters as mycelium in dormant buds infected during the previous growing season. Conidia produced on the mycelium serve as primary inoculum. Healthy buds often open earlier than infected buds, thus providing susceptible tissue upon conidia development. Limited germination occurs at high temperatures or in free water. High concentrations of spores are released in the air from midday to early afternoon. Infection of young or mechanically damaged leaves, blossoms and fruit serve as a secondary source of inoculum.

\section{Management:}

Dormant season pruning may remove infected buds and reduce the level of primary inoculum. During the growing season severely infected shoots should be pruned and destroyed. Prevention of new spores and reduction of spores produced on new lesions may be accomplished through fungicide sprays. See Table 1.

\section{RUST}

\section{Introduction:}

Several related rust fungi infect apple in the southeastern United States, including cedar apple rust, quince rust, and American hawthorn rust. These fungi involve two host plants in their life cycle, usually requiring a Juniperus species as an alternate host. The various fungi differ in life cycle complexity and whether they affect fruit, leaves, or both.

\section{Symptoms:}

Cedar apple rust affects leaves, petioles and fruit, beginning as small yellow lesions (upper surface of leaves) which may be surrounded by chlorotic halo or red band. Small orange-brown pustules (pycnia) develop within the lesions, producing watery orange drops. Later, yellow-brown lesions form on the undersurface of leaves which produce small, dark tubular structures (aecia) that fracture to release red-brown spores (Fig. 11). Fruit lesions are usually superficial, causing a brown necrosis $1-5 \mathrm{~mm}$ into the flesh (Fig. 12). Cedar apple rust on alternate host juniper often forms a gelatinous horned gall (Fig. 13). 


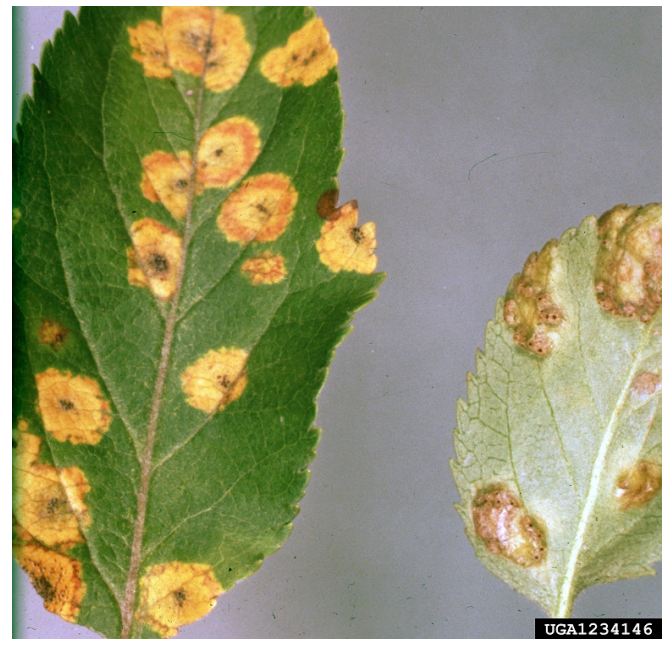

Figure 11. Credits: Clemson University - USDA Cooperative Extension Slide Series (IPM Images, The Bugwood Network)

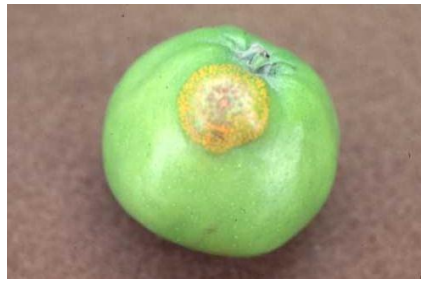

Figure 12. Cedar/Apple rust on apple fruit Credits: Lorraine Berkett, University of Vermont

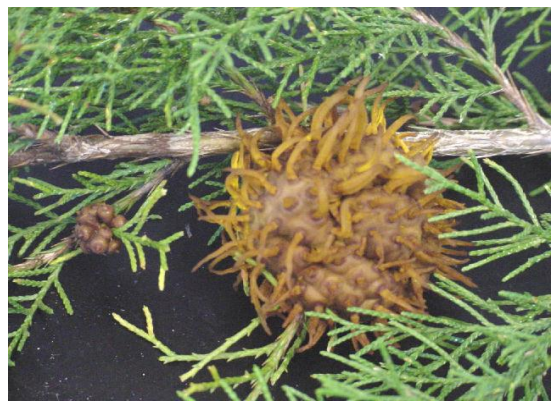

Figure 13. Cedar/Apple rust on alternate host, Juniper. Credits: Hank Dankers, Uiversity of Florida, IFAS, NFREC,Quincy

Quince rust does not affect apple leaves but it does affect fruit. However, obvious rust symptoms (such as pycnia and aecia) are often not present. American hawthorn rust infects apple leaves, but rarely infects fruit.

\section{Causal Organism:}

Various Gymnosporangium species are the causal organisms of rust on apple. Morphologies of fungal structures vary between species.

\section{Disease Cycle and Epidemiology:}

On native cedars Gymnosporangium sp. will induce a gall, from which telial horns will emerge under wet conditions. During rains telia swell and appear jellylike, releasing teliospores which then germinate to produce basidiospores. Basidiospores are immediately discharged into the air and can travel more than 1 mile on air currents; those landing on susceptible apple tissue may germinate and infect the host if a film of water is present for a suitable length of time. Aeciospores are later released from aecia during dry weather and may germinate and infect native cedars.

\section{Management:}

Removal of infected native cedars within close proximity may reduce infection pressure, however, elimination is unlikely as basidiospores can travel great distances. Rust is best controlled using fungicides. See Table 1.

\section{SOOTY BLOTCH}

\section{Introduction:}

Sooty blotch is a late summer disease of apple whereby fruit quality is lowered by fungal growth on the fruit surface. Due to the warm, moist weather, fungicide use is essential in the southeastern United States.

\section{Symptoms:}

Sooty blotch colonies appear as olive green, soot-like smudges on mature fruit. Large portions of the fruit surface may be covered by colonies due to secondary spread on the fruit (Fig. 14).

\section{Causal Organism:}

Gloeodes pomigena is the causal organism of sooty blotch. Produced in the thallus, pycnidia are dark brown, scattered or aggregate, and dimidiate. Conidia are variable in length, generally cigar-shaped, with slight constrictions at the point of septation. Spores in mass are cream to pinkish in color. 


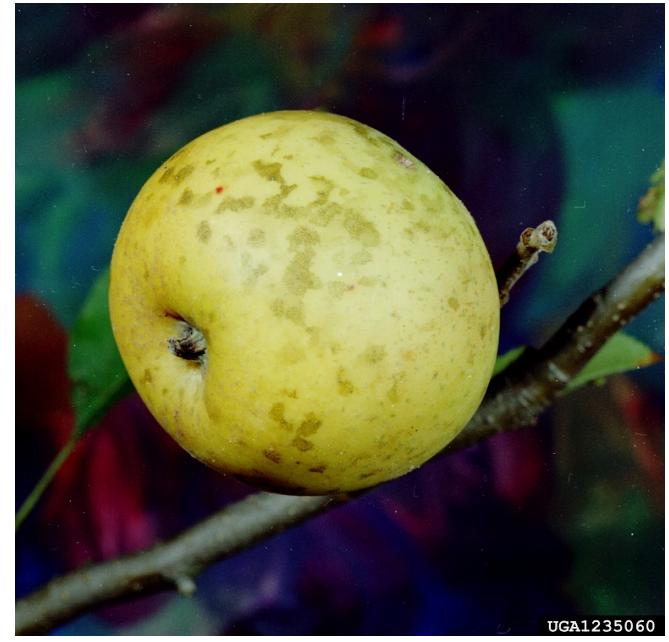

Figure 14. Sooty mold on apple. Note Fly speck. Credits: Clemson University - USDA Cooperative Extension Slide Series (IPM Images, The Bugwood Network)

\section{Disease Cycle and Epidemiology:}

Sooty blotch survives between seasons as mycelium and pycnidia on infected twigs of apple and reservoir hosts (woody plants common to hedgerows and woodlots). Spores are released during spring and early summer rains. Infection can occur any time, but is most noticeable during late season. Mycelial growth is possible despite a lack of free water at relative humidities above $90 \%$.

\section{Management:}

During normal to dry weather, well-pruned trees will usually have less disease. During wet seasons well-pruned and poorly pruned trees may be equally diseased. Proper thinning of fruit lessens the microclimate for disease development that tightly clustered fruit provides and allows for thorough coverage of fungicide sprays. Primary control of sooty blotch is through fungicide sprays. See Table 1.

\section{SOUTHERN BLIGHT}

\section{Introduction:}

Southern blight occurs in orchards and nurseries on trees approximately 3 years old and younger. Due, in part, to the warm, humid weather, tree losses in some southeastern United States have reached 30\% due to this disease.

\section{Symptoms:}

A coarse, white mycelial mat is often found at the base of an infected tree, progressing upward. Small, white sclerotia develop within the mycelium, later turning tan to brown. Leaves of an infected tree may exhibit a reddish or grayish purple discoloration, later drying and turning brown as the fungus girdles the crown and the tree dies.

\section{Causal Organism:}

Sclerotium rolfsii is the causal organism of southern blight. Grown on a wide range of media, the fungus produces white mycelium and reddish brown to dark brown or tan, hard, round sclerotia. No asexual spores are produced.

\section{Disease Cycle and Epidemiology:}

Sclerotia are easily dislodged from mycelium and fall into soil, where they can survive for several years. Infection occurs directly through both injured and healthy bark. Warm summer temperatures $\left(77-95^{\circ} \mathrm{F}\right)$, high soil moisture, good soil aeration and plentiful organic debris promote a high incidence of disease.

\section{Management:}

Delay placement of apple trees where legumes or solanaceous crops have been grown until the area has been deep-plowed, fallowed for a season, and fumigated.

\section{INFORMATION SOURCES}

American Phytopathological Society. 1990. Compendium of Apple and Pear Diseases.

Simone, Gary W., Mullin, R.S. 2000. 1999-2000 Florida Plant Disease Management Guide Volume 3: Fruit and Vegetables.

CDMS Chem Search. http://premier.cdms.net/webapls 
Table 1. Fungicides approved for disease managment of Apple in Florida.

\begin{tabular}{|c|c|c|c|c|c|c|}
\hline & & \multicolumn{2}{|c|}{ Max rate/acre } & & & \\
\hline Chemical (a.i.) & $\begin{array}{l}\text { Fungicide } \\
\text { Group }\end{array}$ & Application & Season & $\begin{array}{l}\text { Min. days } \\
\text { to harvest }\end{array}$ & Disease & Remarks $^{2}$ \\
\hline $\begin{array}{l}\text { Captan 50WP, Captan } \\
\text { 50W } \\
\text { (captan) }\end{array}$ & M3 & $4-8 \mathrm{lb}$ & $64 \mathrm{lb}$ & 0 & $\begin{array}{l}\text { Bitter rot, Black rot, } \\
\text { Botryosphaeria rot, } \\
\text { Flyspeck, Powdery } \\
\text { mildew, Scab, } \\
\text { Sooty blotch }\end{array}$ & \\
\hline $\begin{array}{l}\text { Basic Copper 53, } \\
\text { Cuprofix Disperss } \\
\text { (basic copper sulfate) }\end{array}$ & M1 & $1-5 \mathrm{lb}$ & $32 \mathrm{lb}$ & 0 & $\begin{array}{l}\text { Bitter rot, } \\
\text { Fireblight, } \\
\text { Flyspeck, Powdery } \\
\text { mildew, Scab, } \\
\text { Sooty blotch, White } \\
\text { rot }\end{array}$ & $\begin{array}{l}\text { See label for use } \\
\text { with hydrated lime }\end{array}$ \\
\hline $\begin{array}{l}\text { Kocide 101, } \\
\text { Champion WP, Nu } \\
\text { Cop 50WP } \\
\text { (copper hydroxide) }\end{array}$ & M1 & $1-16 \mathrm{lb}$ & & 1 & Fireblight, Scab & $\begin{array}{l}\text { Varying rates for } \\
\text { desired fruit finish }\end{array}$ \\
\hline $\begin{array}{l}\text { Kocide } 2000 \text {, Kocide } \\
\text { DF, Nu Cop 50DF } \\
\text { (copper hydroxide) }\end{array}$ & M1 & $0.75-6 \mathrm{lb}$ & & 1 & Fireblight, Scab & $\begin{array}{l}\text { Varying rates for } \\
\text { desired fruit finish }\end{array}$ \\
\hline $\begin{array}{l}\text { Kocide 4.5LF, Champ } \\
\text { Formula 2F, Nu Cop } \\
3 \mathrm{~L} \\
\text { (copper hydroxide) }\end{array}$ & M1 & 1.3-10.6 pt & & 1 & Fireblight, Scab & $\begin{array}{l}\text { Varying rates for } \\
\text { desired fruit finish }\end{array}$ \\
\hline $\begin{array}{l}\text { Dithane DF } \\
\text { Rainshield, Manzate } \\
\text { 75DF, Penncozeb } \\
\text { (mancozeb) }\end{array}$ & M2 & $3-6.4 \mathrm{lb}$ & $21-25.6 \mathrm{lb}$ & 77 & $\begin{array}{l}\text { Entomosporium } \\
\text { leaf spot, } \\
\text { Fireblight, Rusts, } \\
\text { Scab }\end{array}$ & $\begin{array}{l}\text { For Fireblight mix } \\
\text { with Copper }\end{array}$ \\
\hline $\begin{array}{l}\text { Dithane F45 } \\
\text { Rainshield, Manzate } \\
\text { Flowable } \\
\text { (mancozeb) }\end{array}$ & M2 & $2.4-4.8 \mathrm{pt}$ & 16.8-19.2 pt & 77 & $\begin{array}{l}\text { Entomosporium } \\
\text { leaf spot, } \\
\text { Fireblight, Rusts, } \\
\text { Scab }\end{array}$ & $\begin{array}{l}\text { For Fireblight mix } \\
\text { with Copper }\end{array}$ \\
\hline $\begin{array}{l}\text { Dithane M45, Manzate } \\
\text { Pro-Stick, Penncozeb } \\
\text { 80WP } \\
\text { (mancozeb) }\end{array}$ & M2 & $3-6 \mathrm{lb}$ & $21-24 \mathrm{lb}$ & 77 & $\begin{array}{l}\text { Entomosporium } \\
\text { leaf spot, } \\
\text { Fireblight, Rusts, } \\
\text { Scab }\end{array}$ & $\begin{array}{l}\text { For Fireblight mix } \\
\text { with Copper }\end{array}$ \\
\hline $\begin{array}{l}\text { Maneb 75DF, Maneb } \\
\text { 80WP } \\
\text { (maneb) }\end{array}$ & M2 & $3-6 \mathrm{lb}$ & $21-25.6 \mathrm{lb}$ & 77 & $\begin{array}{l}\text { Entomosporium } \\
\text { leaf spot, Flyspeck, } \\
\text { Scab, Sooty blotch }\end{array}$ & \\
\hline $\begin{array}{l}\text { Manex } \\
\text { (maneb) }\end{array}$ & M2 & $2.4-4.8 \mathrm{oz}$ & $16.8-19.2 \mathrm{oz}$ & 77 & $\begin{array}{l}\text { Entomosporium } \\
\text { leaf spot, Flyspeck, } \\
\text { Scab, Sooty blotch }\end{array}$ & \\
\hline $\begin{array}{l}\text { Nova } 40 \mathrm{~W}, \text { Rally } 40 \mathrm{~W}, \\
\text { Rally } 40 \mathrm{WSP} \\
\text { (myclobutanil) }\end{array}$ & 3 & $\begin{array}{l}1.25-2.5 \\
o z / 100 \mathrm{gal}\end{array}$ & $5 \mathrm{lb}$ & 14 & $\begin{array}{l}\text { Powdery mildew, } \\
\text { Rusts, Scab }\end{array}$ & \\
\hline
\end{tabular}


Table 1. Fungicides approved for disease managment of Apple in Florida.

\begin{tabular}{|c|c|c|c|c|c|c|}
\hline $\begin{array}{l}\text { Agri-Mycin 17, } \\
\text { Streptrol } \\
\text { (streptomycin) }\end{array}$ & 25 & $24-48$ oz & & 50 & Fireblight & \\
\hline $\begin{array}{l}\text { Dusting Sulfur, } \\
\text { Kumulus DF, } \\
\text { Micronized Gold, } \\
\text { Micrthiol Disperss, } \\
\text { Sulfur } 90 \mathrm{~W} \\
\text { (sulfur) }\end{array}$ & M1 & \multicolumn{3}{|c|}{ rate varies, see labels } & $\begin{array}{l}\text { Powdery mildew, } \\
\text { Rust, Scab, Sooty } \\
\text { blotch }\end{array}$ & $\begin{array}{l}\text { Do not use within } 2 \\
\text { weeks of an oil } \\
\text { spray treatment }\end{array}$ \\
\hline $\begin{array}{l}\text { Thiophanate Methyl } \\
\text { 85WDG } \\
\text { (thiophanate methyl) }\end{array}$ & 1 & $0.6-0.8 \mathrm{lb}$ & $3.3 \mathrm{lb}$ & & $\begin{array}{l}\text { Bitter rot, Black rot, } \\
\text { Flyspeck, Powdery } \\
\text { mildew, Scab, } \\
\text { Sooty blotch, White } \\
\text { rot }\end{array}$ & \\
\hline $\begin{array}{l}\text { Topsin M 70WP, } \\
\text { Topsin M WSB } \\
\text { (thiophanate methyl) }\end{array}$ & 1 & $1-1.5 \mathrm{lb}$ & $4 \mathrm{lb}$ & & $\begin{array}{l}\text { Black rot, Flyspeck, } \\
\text { Powdery mildew, } \\
\text { Scab, Sooty } \\
\text { blotch }\end{array}$ & \\
\hline $\begin{array}{l}\text { Ziram 76DF, Ziram } \\
\text { Granuflo } \\
\text { (ziram) }\end{array}$ & M2 & $6-8 \mathrm{lb}$ & $56 \mathrm{lb}$ & 14 & $\begin{array}{l}\text { Bitter rot, Flyspeck, } \\
\text { Rust, Scab, Sooty } \\
\text { blotch }\end{array}$ & \\
\hline \multicolumn{7}{|c|}{$\begin{array}{l}1 \text { Fungicide group (FRAC code): Numbers (1-37) and letters (M, U, P) are used to distinguish the fungicide mode of action } \\
\text { groups. All fungicides within the same group (with same number or letter) indicate same active ingredient or similar mode of } \\
\text { action. This information must be considered for the fungicide resistance management decisions. } \mathrm{M}=\text { Multi site inhibitors, } \\
\text { fungicide resistance risk is low; } \mathrm{U}=\text { Recent molecules with unknown mode of action; } \mathrm{P}=\text { host plant defense inducers. Source: } \\
\text { http://www.frac.info/ (FRAC = Fungicide Resistance Action Committee). } \\
2 \text { Information provided in this table applies only to Florida. Be sure to read a current product label before applying any } \\
\text { chemical. The use of brand names and any mention or listing of commercial products or services in the publication does not } \\
\text { imply endorsement by the University of Florida Cooperative Extension Service nor discrimination against similar products or } \\
\text { services not mentioned. }\end{array}$} \\
\hline
\end{tabular}

